některých českých a slovenských badatelů - klíčové autory, kteří se dané problematice věnují mnoho let a jsou považováni za experty na obou stranách bývalé ,železné opony“. Jde především o M. Tomku, I. Borowik či $\mathrm{P}$. Zuhlenera, ale třeba také D. Pollacka nebo T. Doktora. Naopak často pracuje s poměrně neaktuálními texty „západních" autorů, jakými jsou A. M. Greely či R. Ingelhart. Nejde přitom o to, že by autoři pocházející z této části Evropy měli nějaký patent na rozum, ale o to, že autoři jako Greely či Ingelhart sledují spíše makro trendy, což mnohdy vede $\mathrm{k}$ problematickým syžetům. Nehledě na to, že publikace těchto autorů (alespoň ty, které jsou uvedeny $\mathrm{v}$ závěrečném seznamu literatury) reflektují jen specifickou situaci devadesátých let.

Podobné je to ale i s výzkumy a datovými soubory, které autor používá. Celkem pochopitelně se opírá zejména o velká mezinárodní šetření, jako jsou ISSP či EVS/ WVS. V jejich rámci přitom sleduje celou řadu zajímavých ukazatelů. Naprosto ale opomíjí „regionálnî“ výzkumy, které podle mne mají zásadní relevanci pro vysvětlení specifik a trendů $\mathrm{v}$ naší části Evropy. Jde především o dva výzkumy AUFBRUCH (1997/2007), které byly explicitně zaměřeny na prostor bývalého sovětského bloku.

I přes tyto výtky však mohu knihu Pavola Minárika doporučit všem, kteří se zajímají o současnou náboženskou situaci nejen u nás, ale i v dalších zemích bývalého sovětského bloku, především pak těm, kteři jsou již tak trochu unaveni $\mathrm{z}$ historických studií a hledají nové perspektivy. Právě v jejich vymezování je Minárikův text velmi inspirativní, a to i přes to, že nebudu souhlasit s některými jeho interpretacemi a budu mít i výhrady $\mathrm{k}$ aktuálnosti některých dat či zjištění.

DAVID VÁCLAVÍK

Religio: Revue pro religionistiku 28/1, 2020, 107-109.

https://doi.org/10.5817/Rel2020-1-11

This work can be used in accordance with the Creative Commons BY-NC-ND 4.0 International license terms and conditions (https://creativecommons.org/licenses/by-nc-nd/4.0/).

\section{Zuzana Malá, Religious Practices in the Japanese Mountains: From Fleeing the Hells towards the Healthy, Sustainable and Spiritual Practices of the Consumer Society,}

\author{
Brno: Masarykova univerzita \\ 2019, 170 p.
}

\section{ISBN 978-80-210-9197-9.}

Over the last two or three decades, religious sites associated with sacred mountains in Japan and particularly with Shugendō, such as the Ōmine mountains and Dewa Sanzan, have faced growing economic pressures arising from the decline, through the aging of their membership, of the pilgrimage confraternities $(k \bar{o})$ which had long underpinned their religious activities, social infrastructure and economic base. Even before this, sports and leisure activities such as climbing and hiking had drawn attention away from traditional religious practices, and the secularisation of mountains was compounded by a booming tourist industry that had grown out of the expansion of the road network. At Dewa Sanzan, for example, the numbers of pilgrims from "parishes" particularly in Miyagi and Fukushima prefectures are declining, and consequently the livelihood of the lodgings (shukubō) which have traditionally catered for them. In response, Dewa Sanzan Shrine on Mt Haguro has embarked on a series of initiatives based on the traditional cuisine of the shukubo in the village of Tōge at its base, while the shukubo are reinventing themselves as guesthouses using their yamabushi (mountain ascetic) heritage as a draw card. The Shrine also promotes ascetic practices (shugyō) to attract younger people, while one of the shukubō, Daishōbō, has embarked rather successfully on a programme 
aimed particularly at urban youth, a "yamabushi experience" based on a combination of ritual practices derived from the August mountain-entry practice called the Autumn Peak, and those based on water purification, like immersion and standing under a waterfall, which are not part of the traditional practice at Haguro.

The present volume considers the changes in religious practices in the mountains in terms of ongoing reaction to social and economic realities over the centuries, paying particular attention to the concepts of consumerism and commodification. This is not intended as a negative criticism of religious values but as a way of interpreting how people are attracted by what is offered, particularly in terms of personal experience. The first three chapters deal with concepts and practices related to the Tateyama cult down to the $19^{\text {th }}$ century, with the intention of providing a framework for the later examination of the modern Cloth Bridge Consecration Rite. A basic theme of all Shugendō, and by extension, mountain practices, is that of the journey from death to rebirth. It was both the core of the mountain-entry rituals performed by professional yamabushi in premodern times and also the raison d'être of secular pilgrimage supervised by them. Chapter 1 examines preBuddhist Japanese notions of the afterlife, Buddhist hells, visions of the afterlife as described in the early $9^{\text {th }}$ century Nihon ryoiki, the influence of Chinese ideas about judgement and salvation, and literary and pictorial representations of the six reams of rebirth. The great detail is justified because they appear in the imagery of sacred mountains, and in particular, in the Tateyama Mandara discussed in Chapter 2. These devotional paintings place the journey to salvation within the specific geography of the Tateyama mountains, with particular attention placed on the visualisation of the hells described in the previous chapter. The author understands the Tateyama Mandara to be a narrative of the legends and practices of the pilgrimage site and so provides a broad description of the path to the summit through the ten realms, from the hells to buddhahood. She also discusses the founder legend in detail. Chapter 3 studies the pre- modern Tateyama Cult in terms of its associated religious practices, centering on the Cloth Bridge Consecration Rite and focusing on its creation as an alternative practice for women at a time when mountains were taboo to them. The idea of consumerism is applicable here - it provided a practice women wanted - and the author emphasises the importance of religious practices as financial providers.

Unlike the previous chapters, detailed textual studies based solely on secondary sources, the final two chapters derive from the author's fieldwork. Chapter 4 looks at the modern reconstruction of the Cloth Bridge Consecration Rite as cultural heritage and as a "local identity-creating ritual" rather than a religious one. Interestingly, when it was revived in 1996, it was placed in the hands of Tendai and Shingon priests, who were, however, instructed, because it was being funded by the local government, not to make it religious. Sensibly they decided to ignore this impossible demand, and there were no negative repercussions. While the organizers looked at it as a "performance," stressing the ideas of cultural knowledge and the appreciation of nature, participants tended to personalise the experience in more religious or quasi-religious terms. Further rebranding has occurred in the years since, and it is now also associated with spirituality and "healing". Another area of rebranding is the valorisation of nature: coexistence with the environment has been emphasised both as something "Japanese" and as integrally connected with religion. The author notes that Shugendo professionals typically interpret their religion as "knowledge inherited from ancient predecessors" and that its practices "serve as a way to reconnect with nature and also with one's own culture" (p. 101). On the one hand, this may be understood as an aspect of Nihonjinron, and, on the other, a modern interpretation that has nothing to do with traditional religious ideas, even Shugendō. The chapter concludes with a description of a retreat the author attended at Daishōbō in 2014.

Chapter 5 takes a broader look at religious practices in a consumer society, drawing attention to how commodities as sou- 
venirs can reshape a cult and be "useful tool[s] in regional promotion" (p. 107). It also looks at the type of image of religious practices likely to appeal to the modern consumer and takes up shōjin ryōri, vegetarian dishes traditionally associated with Buddhist temples, as an example. Other examples of "choosing experience" are waterfall practice (takigyō), personalised charms, and fire-walking. Such experiences can also be a form of cultural diplomacy: the Cloth Bridge Rite was reenacted in Paris in 2015 and Dewa Sanzan Shrine has presented a shōjin ryōri event in Paris and Budapest (2011) and Milan (2015).

Each chapter has a well-constructed summary at the end, and a Conclusion draws together the diverse themes discussed. The book includes three appendices, "Original Versions of Translations from Japanese", "The Cloth Bridge Consecration Rite", and "Retreat", as well as a Resumé in French, a bibliography, and a list of figures. It is attractively presented with a wealth of well-selected photographs.

Overall, the book would have benefited from significant reorganisation and editing. The first three chapters are entirely based on secondary sources, and are of a detail and style that contrasts with the latter two. It seems as if there are two books here - one about Tateyama itself (which follows closely the work of Fukue Mitsuru, Susanne Formanek and particularly Caroline Hirosawa), and one, far more interesting, about the effect of consumerism, commodification, mediatization, and "performance" on religious practices. However, the fieldwork reports which underlie this part lack specificity and would benefit from a more academic approach in terms of detail, such as names. Here, for example, a study of how Hoshino Fumihiro, the "retreat leader" at Haguro, came to be involved in this activity would have provided a valuable insight into the way actors respond to the demands of a changing society. The author has obviously done a wide range of fieldwork and it would have been useful if she could have, for example, introduced a further dimension to her study by considering another group of participants in mountain practices - namely, Shugendō practitioners like those at Sannōin in Kanuma (Nikko) whom she visited. They provide a telling case for the ways Shugendo training and practices have been modified for those who hold down ordinary jobs in the modern world. Participants in the Akinomine practices at Haguro, held both at Dewa Sanzan Shrine and Kōtakuji temple, as well as those who practice in the Ömine mountains (at Kinpusenji, Shōgōin, Daigoji), are also worth consideration in this context. Finally, given the emphasis on the Tateyama Mandara, a reproduction of the whole scroll would have been useful. Only details appear in the text, and the reader has no idea how they fit together. The translations are occasionally a little awkward, there are a couple of misprints, and the understanding of the source texts has been a little shallow in some instances. Nevertheless, the book contains an interesting thesis and is worth consideration.

\section{GAYNOR SEKIMORI}

Religio: Revue pro religionistiku 28/1, 2020, 109-111.

https://doi.org/10.5817/Rel2020-1-12

This work can be used in accordance with the Creative Commons BY-NC-ND 4.0 International license terms and conditions (https://creativecommons.org/licenses/by-nc-nd/4.0/). 